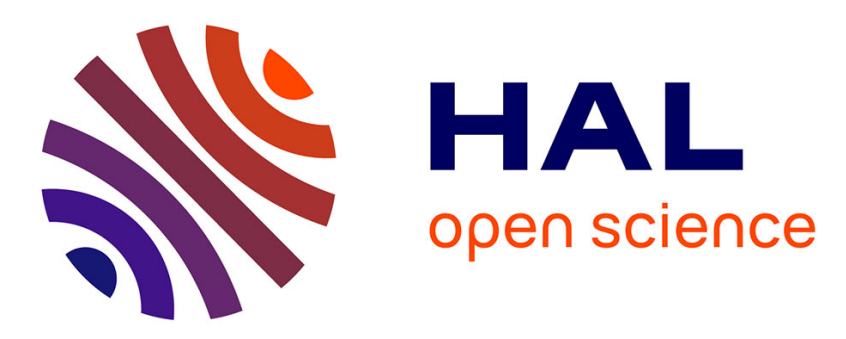

\title{
Synthesis of 5-Substituted 1H-tetrazoles from Nitriles by Continuous Flow. Application to the Synthesis of Valsartan
}

Florian Carpentier, Francois-Xavier Felpin, Françoise Zammattio, Erwan Le Grognec

\section{To cite this version:}

Florian Carpentier, Francois-Xavier Felpin, Françoise Zammattio, Erwan Le Grognec. Synthesis of 5Substituted 1H-tetrazoles from Nitriles by Continuous Flow. Application to the Synthesis of Valsartan. Organic Process Research and Development, 2020, 24 (5), pp.752-761. 10.1021/acs.oprd.9b00526 . hal-03016805

\section{HAL Id: hal-03016805 https://hal.science/hal-03016805}

Submitted on 20 Nov 2020

HAL is a multi-disciplinary open access archive for the deposit and dissemination of scientific research documents, whether they are published or not. The documents may come from teaching and research institutions in France or abroad, or from public or private research centers.
L'archive ouverte pluridisciplinaire HAL, est destinée au dépôt et à la diffusion de documents scientifiques de niveau recherche, publiés ou non, émanant des établissements d'enseignement et de recherche français ou étrangers, des laboratoires publics ou privés. 


\title{
Synthesis of 5-Substituted $1 H$-tetrazoles from Nitriles by Continuous Flow. Application to the Synthesis of Valsartan.
}

Florian Carpentier, François-Xavier Felpin, Françoise Zammattio, Erwan Le Grognec* Université de Nantes, CNRS, CEISAM, UMR 6230, F-44000 Nantes, France

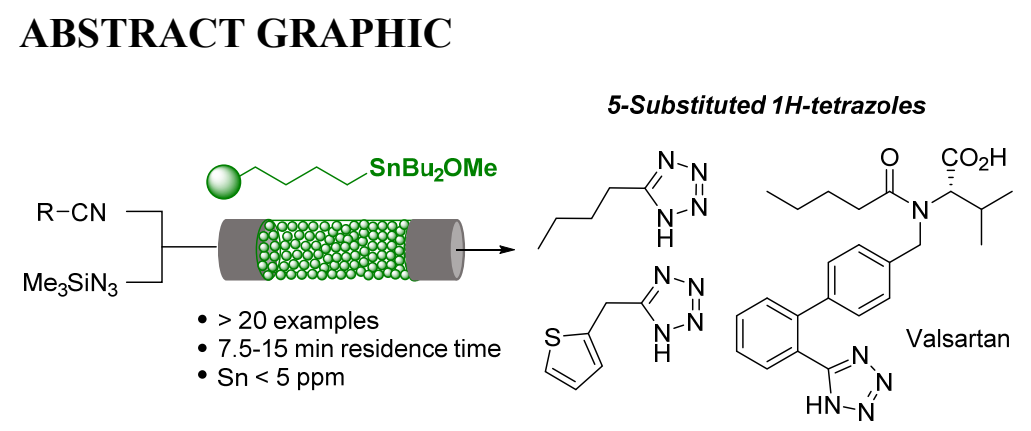

\begin{abstract}
An efficient continuous flow process for the synthesis of 5 -substituted $1 H$-tetrazoles is described. The process involves the reaction between a polymer-supported triorganotin azide and organic nitriles. The polymer-supported organotin azide which is in situ generated with a polystyrene-supported triorganotin alkoxide and trimethylsilylazide, is immobilized in a packed bed reactor. This approach is simple, fast (it takes from 7.5 to $15 \mathrm{~min}$ ) and guarantees a low concentration of tin residues in the products $(<5 \mathrm{ppm})$. The process was developed to aryl-, heteroaryl- and also alkylnitriles and was applied for the synthesis of valsartan, an angiotensin II receptor antagonist.
\end{abstract}

\section{KEYWORDS}

continuous-flow, tetrazole, organotin, azide, polymer-supported reagent 


\section{- INTRODUCTION}

The tetrazole unit continues to arise a great interest in both academia and industry. Indeed, this heterocycle plays a pivotal role in energetic materials, ${ }^{1}$ supramolecular chemistry and coordination chemistry, ${ }^{2}$ organocatalysis ${ }^{3}$ and medicinal chemistry. ${ }^{4,5}$ This interest is due to their unique structure and properties. In medicinal chemistry, the 5-substituted $1 H$-tetrazole unit is frequently used as a carboxylic acid isostere. ${ }^{6,7}$ Generally, the presence of the tetrazole moiety induces an increased activity, a longer biodisponibility and does not enhance the toxicity of the active pharmaceutical ingredient (API). For these reasons, numerous API containing a tetrazole moiety are currently on the pharmaceutical market (Figure 1).<smiles>CCCCC(=O)N(Cc1ccc(-c2ccccc2-c2nnn[nH]2)cc1)C(C(=O)O)C(C)C</smiles>

valsartan (anti-hypertensive)<smiles>CCCCC1=NC2(CCCC2)C(=O)N1Cc1ccc(-c2ccccc2-c2nnn[nH]2)cc1</smiles>

irbesartan (anti-hypertensive)<smiles>CC(C)C[C@H](NC(=O)C(NC(=O)[C@H](CN)NC(=O)c1nnn[nH]1)C(C)C)C(=O)N[C@@H](c1ccccc1)[C@@H](O)C(=O)Nc1cc(C(=O)O)cc(C(=O)O)c1</smiles>

KMI-429 (treatment of Alzeihmer desease)<smiles>CC1=CC=NC2C(=O)C(c3nnn[nH]3)=CN=C12</smiles>

pemiroplast (antihistaminic)<smiles>Cn1nnnc1SCC1=C(C(=O)O)N2C(=O)C(C)(NC(=O)C(CO)c3ccc(O)cc3)COC2C1=O</smiles>

latamoxef (antibiotic)

Figure 1: Examples of active pharmaceutical ingredients containing a tetrazole moiety

In this context, there is a continuing interest for the development of efficient procedures for the synthesis of tetrazoles and numerous methodologies have been reported. ${ }^{8,9}$ In addition, there is a growing demand for environmentally friendly, energetically efficient and safe procedures. The search for faster and safer procedures often conduct nowadays to the consideration of the continuous flow technology. The latter enhances mass and heat transfer, reduces cost and time for optimization and facilitates the transition from the R\&D to the production. For these reasons 
continuous flow chemistry is now recognized as a powerful technology and several contributions related to the synthesis of tetrazoles in flow have already been reported. ${ }^{10-12}$

From our side, we have recently reported a versatile synthesis of $5 \mathrm{H}$-substituted $1 \mathrm{H}$-tetrazoles 2 through the reaction of trimethylsilylazide with nitriles using a triorganotin alkoxide precatalyst 1, a strategy which was found to be efficient both for substituted aryl or alkyl tetrazoles. ${ }^{13}$ This procedure involves the in situ generation of a triorganotin azide acting as the effective reaction catalyst. Moreover, a heterogeneous version of the reaction was also developed by using a polystyrene-supported organotin reagent. ${ }^{13,14}$ This methodology limits efficiently the amount of residual tin in the reaction product. ${ }^{15,16}$ The high temperatures required for the preparation of tetrazoles in batch associated to the inherent hazardous nature of azides, prompted us to explore a continuous flow approach of our technology. Here we report our effort toward this end which culminated with the synthesis of valsartan, an angiostensin II receptor antagonist.

\section{- RESULTS AND DISCUSSION}

We began our investigations by studying the synthesis of 5-phenyl $1 H$-tetrazole $\mathbf{2 a}$ as a benchmark transformation. The influence of the temperature, residence time and nature of solvent was considered for the first campaign of runs. The results and a schematic representation of the flow device are reported in Table 1. It consists of a single stream equipped with a $1 \mathrm{~mL}$ injection loop (loaded with a preformed solution of benzonitrile, trimethylazide and tributyltin azide), a reactor coil $(3.75 \mathrm{~mL}, 0.76 \mathrm{~mm}$ id) placed in an oven for an accurate control of the temperature and a cooler unit $\left(0^{\circ} \mathrm{C}\right)$ to quickly decrease the reaction temperature. In addition, a back pressure regulator was installed to pressurize the flow system (up to 100 bar) and prevent the solvent to vaporize upon high temperature. Therefore, pressurized continuous flow setup offers the opportunity to work with lower boiling point solvents which can be superheated under the processing conditions. ${ }^{10,17-21}$ Initially the flow rate was kept at $0.375 \mathrm{~mL} / \mathrm{min}$ corresponding to a residence time of $10 \mathrm{~min}$. Our first investigations revealed that neither dibutyl ether nor a mixture of dibutyl ether with THF was compatible with the process due to the precipitation of the reaction product in the cooler device. DMSO was also not compatible, as it solidified in the cooler device, despite the good solubility of tetrazoles in this solvent. We then considered diglyme, THF, DMAc, a mixture of dibutyl ether with DMF (50:50) and acetone and observed that the reaction was rather insensitive to the nature of the solvent (entries 1-5). Therefore, further investigations were pursued in acetone, a solvent having a low boiling point which is not hazardous for health. The influence of the temperature and the 
residence time were then evaluated and we concluded that a residence of $20 \mathrm{~min}$ (with a flow rate of $0.187 \mathrm{~mL} / \mathrm{min}$ ) and a temperature of $200^{\circ} \mathrm{C}$ constituted the best experimental conditions.

Table 1 . Preliminary screening for the continuous-flow tetrazole synthesis.

\begin{tabular}{|c|c|c|c|c|}
\hline \multicolumn{2}{|c|}{$\begin{array}{l}\mathrm{PhCN}, 1.35 \mathrm{M} \\
\mathrm{Me}_{3} \mathrm{SiN}_{3}(1.5 \text { equiv) } \\
\mathrm{Bu}_{3} \mathrm{SnOMe}(10 \mathrm{~mol} \%)\end{array}$} & & & \\
\hline solvent & & & $\begin{array}{l}\text { Back } \\
\text { Pressure } \\
\text { Regulator }\end{array}$ & \\
\hline Entry & Residence time (min & $\mathrm{T}\left({ }^{\circ} \mathrm{C}\right)$ & Solvent & Yield (\%) \\
\hline 1 & 10 & 200 & Diglyme & 35 \\
\hline 2 & 10 & 200 & THF & 34 \\
\hline 3 & 10 & 200 & DMAc & 28 \\
\hline 4 & 10 & 200 & $\mathrm{Bu}_{2} \mathrm{O}: \mathrm{DMF}(50: 50)$ & 36 \\
\hline 5 & 10 & 200 & Acetone & 38 \\
\hline 6 & 10 & 160 & Acetone & 14 \\
\hline 7 & 10 & 180 & Acetone & 32 \\
\hline 8 & 10 & 220 & Acetone & 35 \\
\hline 9 & 20 & 160 & Acetone & 25 \\
\hline 10 & 20 & 180 & Acetone & 44 \\
\hline 11 & 20 & 200 & Acetone & 51 \\
\hline 12 & 20 & 220 & Acetone & 33 \\
\hline
\end{tabular}

With this initial screening in hand, we aimed at the development of a more sustainable approach through the use of an immobilized organotin catalyst. The preparation of the latter and its use in batch for the synthesis of 5-substituted $1 H$-tetrazole has been recently reported by our group. ${ }^{13}$ We demonstrated that the tin alkoxy moiety grafted on insoluble polystyrene afforded good conversions in batch for a large range of nitrile derivatives and allows a facile procedure to recover the reaction products. However, this procedure suffered from long reaction times (18 h). We reasoned that transferring this technology within a continuous flow system should certainly address this drawback. Indeed, the immobilization of catalysts in cartridges considerably increases their local concentration and significantly speed-up reaction rates. ${ }^{22}$ Therefore, we considered a stainless steel column $(4.6 \times 50 \mathrm{~mm})$ filled with the heterogeneous catalyst to perform new runs and optimize the reaction conditions (Table 2). 
Table 2. Optimization for the heterogeneous continuous flow tetrazole synthesis in acetone.

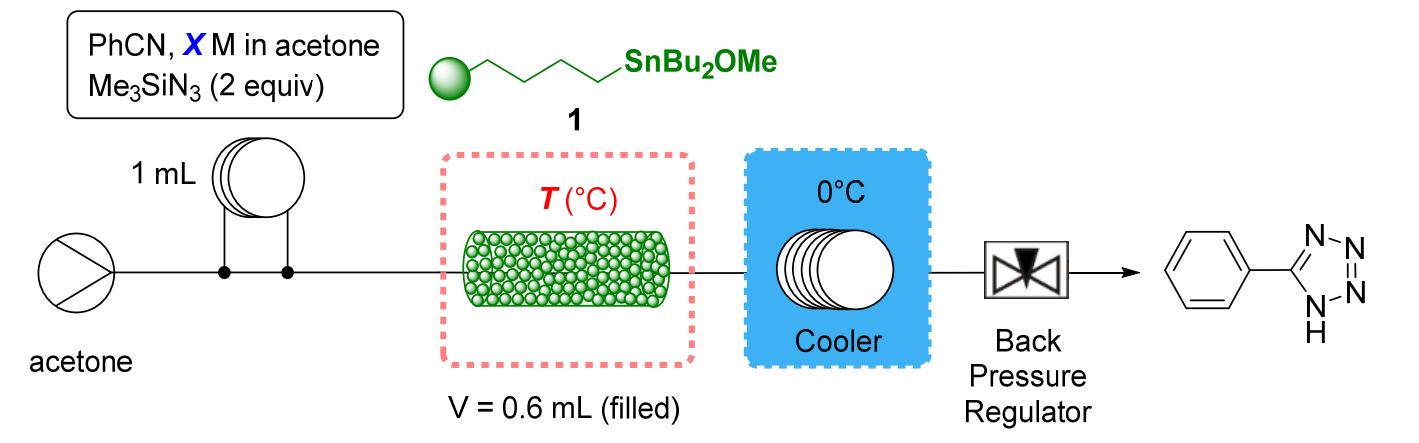

\begin{tabular}{ccccc}
\hline Entry & $\mathrm{T}\left({ }^{\circ} \mathrm{C}\right)$ & Residence time $(\mathrm{min})^{\mathrm{a}}$ & Conc. $X(\mathrm{~mol} / \mathrm{L})$ & ${\text { Yield }(\%)^{\mathrm{b}}}^{\mathrm{a}}$ \\
\hline 1 & 160 & 7.5 & 0.19 & 41 \\
2 & 160 & 15 & 0.19 & 71 \\
3 & 180 & 7.5 & 0.19 & 63 \\
4 & 180 & 15 & 0.19 & 79 \\
$\mathbf{5}$ & $\mathbf{2 0 0}$ & $\mathbf{7 . 5}$ & $\mathbf{0 . 1 9}$ & $\mathbf{8 4}$ \\
6 & 200 & 15 & 0.19 & 78 \\
7 & 220 & 7.5 & 0.19 & 77 \\
8 & 160 & 7.5 & 0.5 & 21 \\
9 & 180 & 7.5 & 0.5 & 66 \\
10 & 200 & 15 & 1 & 65 \\
11 & 180 & 15 & 1 & 39 \\
12 & 200 & 15 & 0.5 & 80 \\
13 & 200 & 1 & 72 \\
\hline
\end{tabular}

The back pressure regulator was set at 35 bar. a. flow $=0.08 \mathrm{~mL} / \mathrm{min}$ for a residence of $7.5 \mathrm{~min}$ and $0.04 \mathrm{~mL} / \mathrm{min}$ for 15 min. b NMR yields were determined using trimethylbenzene as internal standard.

Under these conditions, we studied the influence of the temperature, the residence time and the benzonitrile concentration (X) on the reaction yield (entries 1-6). These investigations revealed that a residence time of $7.5 \mathrm{~min}$ at $200{ }^{\circ} \mathrm{C}$ afforded the best yield when the benzonitrile concentration was set at $0.19 \mathrm{~mol} / \mathrm{L}$ ( $84 \%$ yield, entry 5$)$. A good yield was also obtained with a more concentrated benzonitrile solution $(0.5 \mathrm{~mol} / \mathrm{L})$ at $200{ }^{\circ} \mathrm{C}$ when the residence time was increased to $15 \mathrm{~min}$ (entry 12). Unfortunately, increasing the concentration of benzonitrile to 1 $\mathrm{mol} / \mathrm{L}$ was detrimental for the yield regardless of the residence time or the reaction temperature (entries 10,11,13). These results highlight the advantages of using heterogeneous catalysts in flow; the yields from entries 10, 11 and 13 have to be compared with the 51\% yield obtained in $20 \mathrm{~min}$ at $200{ }^{\circ} \mathrm{C}$ with the homogeneous precatalyst, Bu3 SnOMe (Table 1, entry 11).

With these conditions in hand, we explored the scope of the reaction with a set of 20 aromatic, heteroaromatic and aliphatic nitrile derivatives. The results of our screening are depicted in Table 3. Gratifyingly, the developed flow conditions are robust and tolerate a large range of substrates without issues of clogging. Both aryl and heteroaryl tetrazoles were efficiently prepared in good yields under the optimized conditions. In some cases, the reaction proceeded 
with lower yields due to steric hindrance at the ortho positions (compounds $2 \mathbf{2 d}, \mathbf{2 e}, \mathbf{2 j}$ ) but these yields could be improved with a longer residence time (15 $\mathrm{min}$ ). For derivatives resulting from a double cycloaddition reaction, 4 equiv of $\mathrm{Me}_{3} \mathrm{SiN}_{3}$ are required to obtain satisfactory yields $(\mathbf{2 i}, \mathbf{2 t})$. Finally the procedure was also found to be efficient for benzyl $\mathbf{2 0}, \mathbf{2 p}$ and alkyl derivatives $2 \mathbf{q}, \mathbf{2 r}$ even though a residence time of $15 \mathrm{~min}$ proved to be necessary to obtain yields above $70 \%$. The space time yields were calculated for each derivatives and for example an $87 \mathrm{mmol} / \mathrm{h} / \mathrm{L}$ value was found for compound $\mathbf{2 a}$ (see SI for the complete list of space time yields). In addition, upon successive injections, a mass of $1.066 \mathrm{~g}$ of compound $\mathbf{2 a}$ could be produced indicating that the process could be scaled up. Finally, I has to be noted that ICP-MS analyses carried out on three compounds (2a, 2e and $\mathbf{2 q})$ exhibited low concentration of tin residue (less than $5 \mathrm{ppm}$ ). 
Table 3. Scope of the reaction catalyzed by the heterogeneous catalyst in continuous flow.

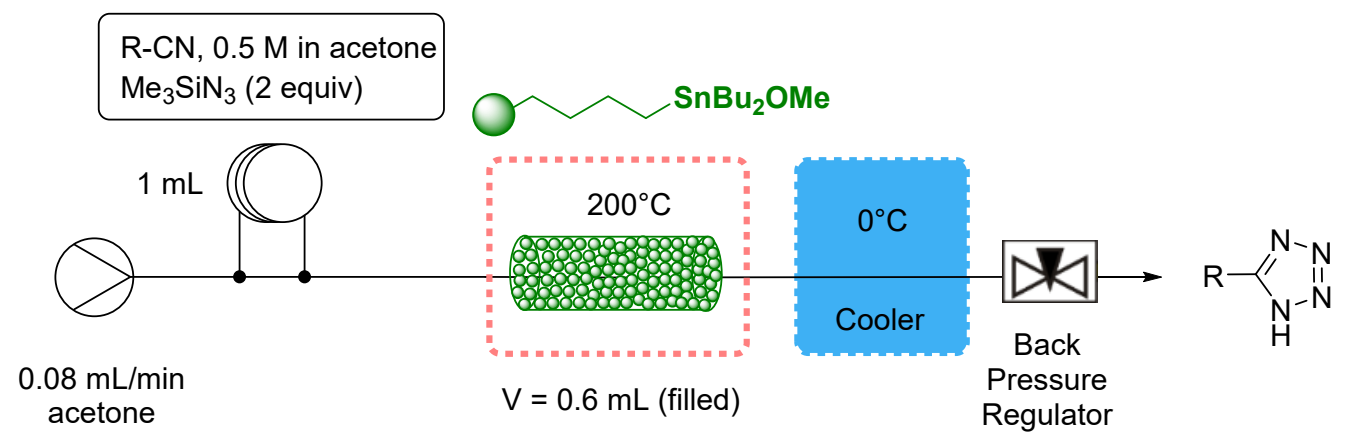

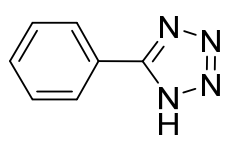

$2 \mathbf{a}$

$84 \%$<smiles>c1ccc(-c2ccccc2-c2nnn[nH]2)cc1</smiles>

$2 e$

$46 \%$

$63 \%$ a

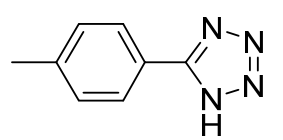

2b

$65 \%$

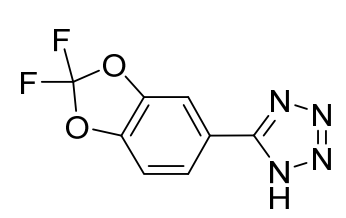

$2 f$

$48 \%$

$71 \%$

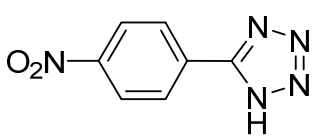

2c

$71 \%$

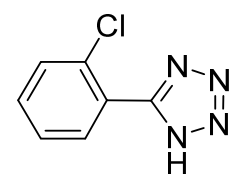

2d

$48 \%$

$91 \% a$<smiles>c1cc(-c2nnn[nH]2)nc(-c2nnn[nH]2)c1</smiles><smiles>OC1C=CC=C2C=CC(c3nnn[nH]3)=NC21</smiles>

$2 \mathbf{i}$

$48 \%^{b}$

2j

$69 \%{ }^{a}$<smiles>C1CN(c2nnn[nH]2)CCO1</smiles><smiles>C1CCN(c2nnn[nH]2)CC1</smiles>

$\underset{76 \%}{\mathbf{2 n}}$

$80 \%$<smiles>C1CCC(c2nnn[nH]2)C1</smiles>

$2 r$

$60 \%$

$78 \%$

$76 \%$<smiles>c1c[nH]c(-c2nnn[nH]2)c1</smiles><smiles>c1ccc(Cc2nnn[nH]2)cc1</smiles>

20<smiles>c1cncc(-c2nnn[nH]2)c1</smiles>

29

\section{2k}

$63 \%$

$77 \%$<smiles>c1csc(Cc2nnn[nH]2)c1</smiles>

$2 s$

$50 \%$

$93 \%$<smiles>c1csc(-c2nnn[nH]2)c1</smiles><smiles>c1ccc(-c2nnn[nH]2)nc1</smiles>

$2 h$

$84 \%$<smiles>c1ccc(C(c2ccccc2)c2nnn[nH]2)cc1</smiles>

$2 p$

$62 \%$<smiles>c1nn[nH]c1Cc1nnn[nH]1</smiles>

$2 t$

$50 \%{ }^{b}$

Yields refer to isolated products; the back pressure regulator was set at 35 bar. a. Flow $=0.04 \mathrm{~mL} / \mathrm{min}$, residence time $=15 \mathrm{~min}$; $\mathrm{b}$. Use of 4 equiv of $\mathrm{TMSN}_{3}$. 
Our technology was applied to the synthesis of valsartan, an angiotensin II receptor blocker, marketed by Novartis company. ${ }^{23-26}$ The synthesis route we developed, depicted in Scheme 1, is a mix between newly developed steps and literature precedents. ${ }^{23-26}$ The palladium-catalyzed Stille cross-coupling of 2-bromobenzonitrile $\mathbf{3}$ and polymer-supported tolyltin $\mathbf{4}$ performed in batch was adapted from a methodology developed earlier in our laboratory, ${ }^{27-31}$ and afforded $\mathbf{5}$ in $86 \%$ yield. Polymer-supported tolyltin 4 was readily prepared by lithiation of 4-bromotoluene with tert-butyllithium followed by trapping with the polymer-supported dibutyltin iodide (see Supporting Information for details). Biphenyl 5 derivative was brominated with $\mathrm{NaBrO}_{3}$ in the presence $\mathrm{Na}_{2} \mathrm{~S}_{2} \mathrm{O}_{5}$ to furnish benzylbromide 6 in 94\% yield. This procedure significantly improved the previously described approach using NBS/AIBN which, in our hand, furnished a mixture of mono- and dibromo compounds in a 80/20 ratio. ${ }^{32}$ The L-valine moiety was installed by substitution of the bromine atom in a biphasic media using TBAB as phase transfer agent and $\mathrm{K}_{2} \mathrm{CO}_{3}$ as base to give 7 in high yield (90\%). Switching $\mathrm{K}_{2} \mathrm{CO}_{3}$ for $N, N$ diisopropylethylamine as a base and working under anhydrous conditions provided 7 , in our hand, in much lower yield (80\%). ${ }^{32}$ The secondary amine 7 was acylated with pentanoic acid chloride in the presence of $N, N$-diisopropylethylamine in toluene to give compound $\mathbf{8}$ in $96 \%$ yield. Then, the buildup of the tetrazole ring was accomplished following the above-described procedure applied to nitrile 8 . The latter afforded the benzyl valsartan derivative 9 in $50 \%$ with a residence time of $15 \mathrm{~min}$. The final hydrogenolysis of the benzyl ester furnished valsartan in $60 \%$ yield. An ICP-MS analysis revealed a low residual tin concentration ( $3 \mathrm{ppm}$ ) although two different reactions of this multi-step synthesis were carried out with an organotin reagent. This result demonstrates the efficiency of the polymer-supported strategy applied to organotin chemistry associated to the continuous flow technology and address pharmaceutical requirements, the upper limit of $\mathrm{Sn}$ level being $\sim 20 \mathrm{ppm} .{ }^{33,34}$ Moreover, this process cannot produce nitrosamines whose presence as byproducts in APIs (in valsartan or sartan-type products notably) has been responsible for recalls recently. ${ }^{35}$ 


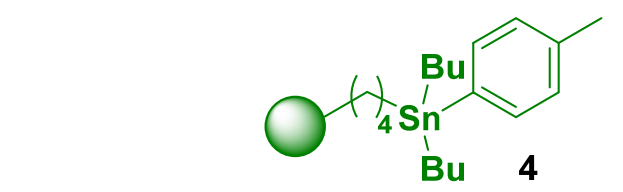<smiles>N#Cc1ccccc1Br</smiles>

3

\section{$\mathrm{PdCl}_{2}\left(\mathrm{PPh}_{3}\right)_{2} \mathrm{LiCl}$ \\ toluene, $100{ }^{\circ} \mathrm{C}, 2 \mathrm{~h}$} $86 \%$<smiles>Cc1ccc(-c2ccccc2C#N)cc1</smiles>

5<smiles>N#Cc1ccccc1-c1ccc(CBr)cc1</smiles>
$80 \%$
6

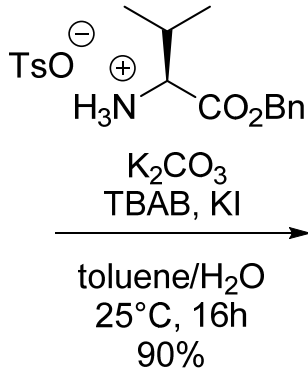

$90 \%$

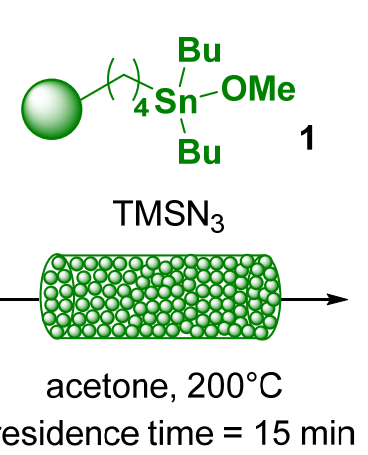

$50 \%$<smiles>CC(C)[C@H](NCc1ccc(-c2ccccc2C#N)cc1)C(=O)OCc1ccccc1</smiles>

7

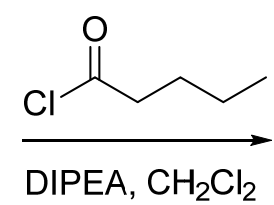

$0{ }^{\circ} \mathrm{C}$ to $25^{\circ} \mathrm{C}, 2 \mathrm{~h}$

$96 \%$

Molecular Weight: 525,65

Molecular Weight: 482,62<smiles>CCCCC(=O)N(Cc1ccc(-c2ccccc2C#N)cc1)[C@@H](C(=O)OCc1ccccc1)C(C)C</smiles><smiles>CCCCC(=O)N(Cc1ccc(-c2ccccc2-c2nnn[nH]2)cc1)[C@@H](C(=O)OCc1ccccc1)C(C)C</smiles>

9<smiles>CCCCC(=O)N(Cc1ccc(-c2ccccc2-c2nnn[nH]2)cc1)[C@@H](C(=O)O)C(C)C</smiles>

10

Scheme 1: Synthesis of valsartan

\section{- CONCLUSION}

An efficient continuous flow process involving a polystyrene-supported organotin reagent was developed for the synthesis of 5-substituted $1 H$-tetrazoles from nitriles. Substituted aryl and alkyl derivatives can be efficiently prepared in a short reaction time $(7.5 \mathrm{~min}$ or $15 \mathrm{~min}$ for the less reactive nitriles) and can be readily isolated in high purity with a low concentration of tin residues (less than $5 \mathrm{ppm}$ ). As a testimony for the usefulness of this protocol for the synthesis of 5-Substituted $1 H$-tetrazoles, we realized the synthesis of valsartan, an angiotensin II receptor antagonist. 


\section{- EXPERIMENTAL SECTION}

\section{General Methods.}

All commercial reagents were used as received. Silica gel $(40-63 \mu \mathrm{m})$ was used in flash column chromatography. Analytical thin-layer chromatography (TLC) was performed on silica gel plates (TLC silica gel 60 F254), visualized with a UV lamp (254 nm), and stained with a solution of vanillin. Solvent systems and flash column chromatography are reported as percent by volume values. ${ }^{1} \mathrm{H},{ }^{13} \mathrm{C}$ and ${ }^{119} \mathrm{Sn}$ NMR spectra were recorded on Bruker Avance 300 or Bruker ARX 400 instruments. Chemical shifts are given in ppm as $\delta$ values related to tetramethylsilane $\left({ }^{1} \mathrm{H},{ }^{13} \mathrm{C}\right)$ and coupling constants are given in $\mathrm{Hz}$. Carbon chemical shifts were internally referenced to the deuterated solvent signals in DMSO ( $\delta 39.52 \mathrm{ppm})$. Mass spectra were obtained in EI $(70 \mathrm{eV})$ and/or CI mode in direct introduction mode using a HP apparatus (Engine 5989A) or a DSQII (ThermoFisher Scientific). HRMS in ESI mode were recorded on a LTQ-Orbitrap (ThermoFisher Scientific). IR spectra were recorded on a Bruker IFS Vector 22 apparatus in ATR mode. Optical rotations were measured on a Perkin-Elmer 341 apparatus and melting points were determined with a Tottoli SMP3 Stuart apparatus. Sample loops were made out of PEEK with a $0.76 \mathrm{~mm}$ internal diameter. The flow rate precision of our pump was less than $0.1 \%$ RSD and the flow accuracy is $\pm 2 \mu \mathrm{L}$. ICP analyses were performed at the Institut des Sciences Analytiques in Villeurbanne. Bu3SnOMe catalyst and polymer-supported organotin alkoxide 1 were prepared according previously described procedures. ${ }^{13} \mathrm{TMSN}_{3}$ is a flammable and toxic compound which should not be used with strong acids, oxidants and heavy metals. It must be handled with gloves under a well ventilated fume hood.

\section{Procedure for the optimization of homogeneous synthesis of 5-substituted $1 \mathrm{H}$-tetrazoles using a flow device:}

The reaction was conducted in a stainless steel reactor coil (1/16" od, $0.75 \mathrm{~mm} \mathrm{id)} \mathrm{with} \mathrm{a}$ volume of $3.2 \mathrm{~mL}$. A solution of benzonitrile (1 equiv), tributyltin methoxide (0.1-1 equiv) and $\mathrm{TMSN}_{3}(1.5-2$ equiv) in the corresponding solvent (0.3-1.3 mol/L) was loaded in an injection loop $(1 \mathrm{~mL})$. The solvent was continuously added with a flow of $160-320 \mu \mathrm{L} / \mathrm{min}$. The reaction was conducted at the indicated temperature. The reaction mixture was collected and concentrated. Trimethylbenzene was added as an internal standard and a ${ }^{1} \mathrm{H}$ NMR was recorded in DMSO- $d_{6}$ to calculate the NMR yield.

\section{Procedure for the optimization of heterogeneous synthesis of 5-substituted $1 \mathrm{H}$-tetrazoles using a flow device.}


The reaction was conducted in a stainless steel column $(4.6 \times 50 \mathrm{~mm})$ filled with $280-340 \mathrm{mg}$ of supported tin catalyst. The residual volume of the column filled was $0.6 \mathrm{~mL}$ as measured with a solution of methylene blue. A solution of benzonitrile (1 equiv) and $\mathrm{TMSN}_{3}$ (2 equiv) in dry acetone $(0.2-1 \mathrm{~mol} / \mathrm{L})$ was loaded in an injection loop $(1 \mathrm{~mL})$. Dry acetone was continuously added with a flow of $40-80 \mu \mathrm{L} / \mathrm{min}$. The reaction was conducted at the indicated temperature. The reaction mixture was collected and concentrated. The reaction mixture was collected and concentrated. Trimethylbenzene was added as an internal standard and NMR was made in DMSO- $d_{6}$ to have NMR yield.

\section{General procedure for the heterogeneous synthesis of 5-substituted $1 \mathrm{H}$-tetrazoles using a flow device.}

The reaction was conducted in a stainless steel column $(4.6 \times 50 \mathrm{~mm})$ filled with $340 \mathrm{mg}$ of supported tin catalyst $1(1.13 \mathrm{mmol} / \mathrm{g})$. The residual volume of the column filled was $0.6 \mathrm{~mL}$, as measured with a solution of methylene blue. A solution of nitrile (1 equiv) and $\mathrm{TMSN}_{3}(2$ equiv) in dry acetone $(0.5 \mathrm{~mol} / \mathrm{L})$ was loaded in an injection loop $(1 \mathrm{~mL})$. Dry acetone was continuously added with a flow of $80 \mu \mathrm{L} / \mathrm{min}$ unless otherwise indicated. The reaction was conducted at the indicated temperature. The reaction mixture was collected and concentrated. Ethyl acetate and $\mathrm{NaOH}(1 \mathrm{M})$ was added and stirred during $30 \mathrm{~min}$. The aqueous phase was acidified with $\mathrm{HCl}$ until $\mathrm{pH} \mathrm{1-2}$ and then extracted with ethyl acetate. The organic phase was washed with brine and was dried over magnesium sulfate, filtered and concentrated under reduced pressure to give the product.

5-phenyl-1H-tetrazole, 2a. General procedure afforded compound 2a as a white solid (61.5 mg, 84\%). m.p. $212-214{ }^{\circ} \mathrm{C}$ with decomp. [lit. ${ }^{36} 215^{\circ} \mathrm{C}$ ]. IR (ATR) v 3200-2400 (br), 1609, 1562, 1485, 1462, 1409, 1162, 989, 785, 682. ${ }^{1} \mathrm{H}$ NMR (400 MHz, DMSO-d6) $\delta$ 8.06-8.03 (m, 2H), 7.62-7.58 (m, 3H). ${ }^{13} \mathrm{C}$ NMR (100 MHz, DMSO- $\left.d_{6}\right) \delta 155.33,131.17,129.36,126.92$, 124.17. HRMS (ESI) $m / z[\mathrm{M}+\mathrm{H}]^{+}$Calcd for $\mathrm{C}_{7} \mathrm{H}_{7} \mathrm{~N}_{4}$ 147.0671; Found 147.0665.

5-(4-Tolyl)-1H-tetrazole, $2 \mathrm{~b}$. General procedure afforded compound $\mathbf{2 b}$ as a white solid (52 mg, 65\%). m.p. $249-251{ }^{\circ} \mathrm{C}$ with decomp. [lit. ${ }^{37} 246-248{ }^{\circ} \mathrm{C}$ with decomp]. IR (ATR) v 32002200 (br), 1615, 1569, 1503, 1437, 1403, 1162, 987, 818, 740, 501. ${ }^{1} \mathrm{H}$ NMR (400 MHz, DMSO- $\left.d_{6}\right) \delta 3.71(\mathrm{t}, J=4.9 \mathrm{~Hz}, 4 \mathrm{H}), 3.35(\mathrm{t}, J=4.9 \mathrm{~Hz}, 4 \mathrm{H}) .{ }^{13} \mathrm{C}$ NMR (100 MHz, DMSO- $\left.d_{6}\right)$ $\delta 159.79,65.15,46.91$. HRMS (ESI) $m / z[\mathrm{M}+\mathrm{H}]^{+}$Calcd for $\mathrm{C}_{8} \mathrm{H}_{9} \mathrm{~N}_{4}$ 161.0822; Found 161.0823. 
5-(4-Nitrophenyl)tetrazole, $2 c$. General procedure afforded compound $2 \mathrm{c}$ as a beige solid (68 mg, 71\%). m.p. $219^{\circ} \mathrm{C}$, [lit. ${ }^{36} 220^{\circ} \mathrm{C}$ ]. IR (ATR) v 3434, 3370, 3225, 3078, 2900-2100 (br), 1608, 1572, 1524, 1337, 1087, 993, 903, 851, 728, 492. ${ }^{1} \mathrm{H}$ NMR (400 MHz, DMSO-d6) $\delta 8.42$ $(\mathrm{d}, J=8.9 \mathrm{~Hz}, 2 \mathrm{H}), 8.28$ (d, $J=8.9 \mathrm{~Hz}, 2 \mathrm{H}) .{ }^{13} \mathrm{C}$ NMR $\left(100 \mathrm{MHz}, \mathrm{DMSO}-d_{6}\right) \delta 155.47,148.70$, 130.65, 128.15, 124.53. HRMS $\left(\mathrm{ASAP}^{+}\right) \mathrm{m} / z[\mathrm{M}+\mathrm{H}]^{+}$Calcd for $\mathrm{C}_{7} \mathrm{H}_{6} \mathrm{~N}_{5} \mathrm{O}_{2}$ 192.0521; Found 192.0521 .

5-(2-chlorophenyl)-1H-tetrazole, 2d. General procedure with the flow set at $0.04 \mathrm{~mL} / \mathrm{min}$ afforded product $2 \mathbf{d}$ as a white solid (82 mg, 91\%). m.p. $177{ }^{\circ} \mathrm{C}$ [lit. $\left.{ }^{10} 179-180{ }^{\circ} \mathrm{C}\right]$. IR (ATR) v 3100-2200 (br), 1678, 1621, 1560, 1470, 1443, 1159, 1059, 743. ${ }^{1} \mathrm{H}$ NMR (400 MHz, DMSOd6) $\delta 7.81(\mathrm{dd}, J=7.6,1.7 \mathrm{~Hz}, 1 \mathrm{H}), 7.70(\mathrm{dd}, J=8,1.2 \mathrm{~Hz}, 1 \mathrm{H}), 7.62(\mathrm{td}, J=5.0,3.7 \mathrm{~Hz}, 1 \mathrm{H})$, $7.55(\mathrm{td}, J=5.0,3.7 \mathrm{~Hz}, 1 \mathrm{H}) .{ }^{13} \mathrm{C}$ NMR (100 MHz, DMSO-d6) $\delta 153.64,132.43,131.94$, 131.68, 130.37, 127.69, 124.38. HRMS (ESI) $m / z[\mathrm{M}+\mathrm{H}]^{+}$Calcd for $\mathrm{C}_{7} \mathrm{H}_{6} \mathrm{~N}_{4} \mathrm{Cl} 181.0276$; Found 181.0273 .

5-([1,1'-biphenyl]-2-yl)-1H-tetrazole, 2e. General procedure with the flow set at $0.04 \mathrm{~mL} / \mathrm{min}$ afforded product $2 \mathrm{e}$ as a white solid (71 mg, 63\%). m.p. $141{ }^{\circ} \mathrm{C}$ [lit. $\left.{ }^{38} 142-144{ }^{\circ} \mathrm{C}\right]$. IR (ATR) $v$ 3200-2400 (br), 1599, 1569, 1473, 1388, 1249, 1156, 1114, 1053, 1005, 860, 746, 701. ${ }^{1} \mathrm{H}$ NMR (400 MHz, DMSO-d6) $\delta$ 7.70-7.65 (m, 2H), 7.59-7.54 (m, 2H), 7.32-7.29 (m, 3H), 7.117.08 (m, 2H). ${ }^{13} \mathrm{C}$ NMR (100 MHz, DMSO-d6) $\delta$ 155.26, 141.44, 139.31, 130.86, 130.53, 128.73, 128.16, 127.64, 127.32, 123.80. HRMS (ESI) $m / z[\mathrm{M}+\mathrm{H}]^{+}$Calcd for $\mathrm{C}_{13} \mathrm{H}_{11} \mathrm{~N}_{4}$ 223.0984; Found 223.0984.

5-(2,2-difluorobenzo[d][1,3]dioxol-5-yl)-1H-tetrazole, 2f. General procedure with the flow was set at $0.04 \mathrm{~mL} / \mathrm{min}$ afforded as a beige solid $\mathbf{2 f}(80 \mathrm{mg}, 71 \%)$. m.p. $174{ }^{\circ} \mathrm{C}$. IR (ATR) $v$ 3100-2200 (br), 1636, 1624, 1579, 1491, 1461, 1428, 1232, 1172, 1126, 1027, 988, 916, 861, 822, 744, 711, 602, 433. ${ }^{1} \mathrm{H}$ NMR (400 MHz, DMSO-d6) $\delta 8.01$ (br. d, $\left.J=1.6 \mathrm{~Hz}, 1 \mathrm{H}\right), 7.91$ (br. dd, $J=8.4,1.6 \mathrm{~Hz}, 1 \mathrm{H}), 7.65(\mathrm{~d}, J=8.4 \mathrm{~Hz}, 1 \mathrm{H}) .{ }^{13} \mathrm{C}$ NMR $\left(100 \mathrm{MHz}, \mathrm{DMSO}-d_{6}\right) \delta 155.18$, 144.43, 143.31, 131.15, 123.91, 121.19, 111.11, 108.72. HRMS (ESI) $m / z[\mathrm{M}+\mathrm{H}]^{+}$Calcd for $\mathrm{C}_{8} \mathrm{H}_{5} \mathrm{~N}_{4} \mathrm{O}_{2} \mathrm{~F}_{2} 227.0381$; Found 227.0375.

3-(1H-tetrazol-5-yl)pyridine, 2g. General procedure afforded product $\mathbf{2 g}$ as a brown solid (63 mg, 85\%). m.p. $235-237{ }^{\circ} \mathrm{C}$ with decomp. [lit. ${ }^{10} 239-240{ }^{\circ} \mathrm{C}$ with decomp.]. IR (ATR) $v 3382$, 3063, 3000-2200 (br), 1639, 1608, 1578, 1527, 1470, 1331, 999, 818, 676. ' H NMR (400 MHz, DMSO-d $d_{6} \delta 9.42$ (br. s, $1 \mathrm{H}$ ), 8.89 (br. d, $J=4.6 \mathrm{~Hz}, 1 \mathrm{H}$ ), 8.79 (br. d, $J=8 \mathrm{~Hz}, 1 \mathrm{H}$ ), 7.89 (dd, 
$J=7.9,5.0 \mathrm{~Hz}, 1 \mathrm{H}) .{ }^{13} \mathrm{C} \mathrm{NMR}\left(100 \mathrm{MHz}, \mathrm{DMSO}-d_{6}\right) \delta 153.58,148.48,144.78,138.03,125.72$, 122.48. HRMS (ESI) $m / z[\mathrm{M}+\mathrm{H}]^{+}$Calcd for $\mathrm{C}_{6} \mathrm{H}_{6} \mathrm{~N}_{5}$ 148.0618; found 148.0615.

2-(1H-tetrazol-5-yl)pyridine, $2 \mathrm{~h}$. General procedure applied afforded compound $\mathbf{2 h}$ as a beige solid (62 mg, 84\%). m.p. $213^{\circ} \mathrm{C}\left[\right.$ lit. $\left.^{36} 211^{\circ} \mathrm{C}\right]$. IR (ATR) v 3200-2200 (br), 1599, 1557, 1479, 1452, 1156, 1017, 945, 791, 719, 465. ${ }^{1} \mathrm{H}$ NMR (400 MHz, DMSO- $\left.d_{6}\right) \delta 8.80$ (ddd, $J=4.8$, 1.7, $1 \mathrm{~Hz}, 1 \mathrm{H}), 8.23(\mathrm{dt}, J=7.8,1 \mathrm{~Hz}, 1 \mathrm{H}), 8.08(\mathrm{td}, J=7.8,1.7 \mathrm{~Hz}, 1 \mathrm{H}), 7.63$ (ddd, $J=7.8$, 4.8, 1,1 Hz, 1H). ${ }^{13} \mathrm{C}$ NMR (100 MHz, DMSO-d6) $\delta 154.69,150.04,143.66,138.20,126.06$, 122.58. HRMS (ESI) $m / z$ [M+H] $]^{+}$Calcd for $\mathrm{C}_{6} \mathrm{H}_{6} \mathrm{~N}_{5}$ 148.0618; Found 148.0613.

2,6-di(1H-tetrazol-5-yl)pyridine, 2i. Following the general procedure using 4 equiv of $\mathrm{TMSN}_{3}$, a flash chromatography (eluent DCM/MeOH 9:1 + 0.1\% $\mathrm{HCO}_{2} \mathrm{H}$ ) afforded product as white solid $2 \mathbf{i}(52 \mathrm{mg}, 48 \%)$. m.p. $280{ }^{\circ} \mathrm{C}$ with decomp. [lit. ${ }^{39}<260{ }^{\circ} \mathrm{C}$ ]. IR (ATR) $v 3200$ 2400 (br), 1687, 1602, 1554, 1452, 1180, 1014, 833, 746. ${ }^{1} \mathrm{H}$ NMR (400 MHz, DMSO-d6) $\delta$ $8.34(\mathrm{~m}, 3 \mathrm{H}) .{ }^{13} \mathrm{C}$ NMR (100 MHz, DMSO- $\left.d_{6}\right) \delta 164.89,144.53,140.16,124.36$. HRMS (ESI) $m / z[\mathrm{M}+\mathrm{H}]^{+}$Calcd for $\mathrm{C}_{7} \mathrm{H}_{6} \mathrm{~N}_{9} 216.0746$; Found 216.0739.

2-(1H-tetrazol-5-yl)quinolin-8-ol, 2j. General procedure with flow set at $0.04 \mathrm{~mL} / \mathrm{min}$ gave compound $\mathbf{2} \mathbf{j}$ as a beige solid (74 mg, 69\%). m.p. $230-234{ }^{\circ} \mathrm{C}$ with decomp. IR (ATR) $v 3200-$ 2200 (br), 1602, 1557, 1470, 1440, 1243, 1192, 1140, 1162, 1059, 990, 945, 776, 743. ${ }^{1} \mathrm{H}$ NMR (300 MHz, DMSO-d6) $\delta 9.42$ (br. s, 1H), 8.56, 8.29 (AB-system, ${ }^{2} J_{A B}=8.6 \mathrm{~Hz}, 2 \mathrm{H}$ ), 7.61-7.51 $(\mathrm{m}, 2 \mathrm{H}), 7.22(\mathrm{dd}, J=7.4,1.3 \mathrm{~Hz}, 1 \mathrm{H}) .{ }^{13} \mathrm{C}$ NMR (75 MHz, DMSO- $\left.d 6\right) \delta 155.01,153.12$, $140.89,138.41,137.46,129.60,128.97,119.18,117.92,111.64$. HRMS (ESI) $m / z[\mathrm{M}+\mathrm{H}]^{+}$ Calcd for $\mathrm{C}_{10} \mathrm{H}_{8} \mathrm{~N}_{5} \mathrm{O} 214.0723$; Found 214.0722.

5-(1H-pyrrol-2-yl)-1H-tetrazole, $2 \mathrm{k}$. General procedure gave compound $\mathbf{2 k}$ as a brown solid (45 mg, 63\%). m.p. $225-226^{\circ} \mathrm{C}\left[\right.$ lit. $\left.^{40} 226^{\circ} \mathrm{C}\right]$. IR (ATR) v 3286, 3150, 3008, 2918, 2900-2100 (br), 1630, 1539, 1464, 1352, 1207, 1053, 888, 734, 583. ${ }^{1} \mathrm{H}$ NMR (400 MHz, DMSO-d6) $\delta$ 16.30 (br. s, 1H), 11.96 (br. s, 1H), 7.03-7.02 (m, 1H), 6.81-6.79 (m, 1H), 6.26-6.24 (m, 1H). ${ }^{13} \mathrm{C}$ NMR (100 MHz, DMSO-d $) \delta 149.30,122.52,115.50,110.85,109.60$. HRMS (ESI) $m / z$ $[\mathrm{M}+\mathrm{H}]^{+}$Calcd for $\mathrm{C}_{5} \mathrm{H}_{6} \mathrm{~N}_{5}$ 136.0623; Found 136.0620.

5-(thiophen-2-yl)-1H-tetrazole, 21. General procedure gave compound $\mathbf{2 l}$ as a beige solid (49 mg, 64\%). m.p. $209^{\circ} \mathrm{C}\left[\right.$ lit. $^{39}$ 206-207 $\left.{ }^{\circ} \mathrm{C}\right]$. IR (ATR) v 3105, 3078, 3032, 3000-2200 (br), 1590, 1506, 1406, 1231, 1041, 957, 712. ${ }^{1} \mathrm{H}$ NMR (400 MHz, DMSO-d6) $\delta 7.88$ (dd, $J=5.0,1.1 \mathrm{~Hz}$, 
1H), $7.80(\mathrm{dd}, J=3.7,1.1 \mathrm{~Hz}, 1 \mathrm{H}), 7.29(\mathrm{dd}, J=5.0,3.7 \mathrm{~Hz}, 1 \mathrm{H}) .{ }^{13} \mathrm{C}$ NMR (100 MHz, DMSOd6) $\delta 151.39,130.26,129.06,128.53,125.49$. HRMS (ESI) $m / z[\mathrm{M}+\mathrm{H}]^{+}$Calcd for $\mathrm{C}_{5} \mathrm{H}_{5} \mathrm{~N}_{4} \mathrm{~S}$ 153.0229; Found 153.0223.

4-(1H-tetrazol-5-yl)morpholine, $\mathbf{2 m}$. General procedure gave compound $\mathbf{2} \mathbf{m}$ as a white solid (63 mg, 80\%). m.p. $179{ }^{\circ} \mathrm{C}$ [lit. ${ }^{41} 177^{\circ} \mathrm{C}$ ]. IR (ATR) v 3200-2400 (br), 1606, 1450, 1267, 1103 , 1021, 923, 735, 557. ${ }^{1} \mathrm{H}$ NMR (400 MHz, DMSO-d6) $\delta 7.93$ (d, $\left.J=8 \mathrm{~Hz}, 2 \mathrm{H}\right), 7.41$ (d, $J=8$ $\mathrm{Hz}, 2 \mathrm{H}), 2.39$ (s, 3H). ${ }^{13} \mathrm{C}$ NMR (100 MHz, DMSO-d6) $\delta 155.07,141.17,129.89,126.8,121.26$, 20.98. HRMS (ESI) $m / z[\mathrm{M}+\mathrm{H}]^{+}$Calcd for $\mathrm{C}_{5} \mathrm{H}_{10} \mathrm{~N}_{5} \mathrm{O}$ 1560.880, Found 156.0875.

1-(1H-tetrazol-5-yl)piperidine, $2 \mathrm{n}$. General procedure gave compound $\mathbf{2 n}$ as a beige solid (58 mg (76\%). m.p. $198{ }^{\circ} \mathrm{C}\left[\right.$ lit. $\left.^{41} 199{ }^{\circ} \mathrm{C}\right]$. IR (ATR) v 3080 (br), 2939, 2856, 2801, 2710, 1611, 1463, 1411, 1011, 912, 735, 678. ${ }^{1} \mathrm{H}$ NMR (400 MHz, DMSO-d6) $\delta 14.85$ (br. s, 1H), 3.36 (s, $4 \mathrm{H}), 1.56(\mathrm{~s}, 6 \mathrm{H}) .{ }^{13} \mathrm{C} \mathrm{NMR}\left(100 \mathrm{MHz}, \mathrm{DMSO}-d_{6}\right) \delta 159.28,47.68,24.27,23.30$; HRMS (ESI) $m / z[\mathrm{M}+\mathrm{H}]^{+}$Calcd for $\mathrm{C}_{6} \mathrm{H}_{12} \mathrm{~N}_{5}$ 154.1087; Found 154.1084.

5-benzyl-1H-tetrazole, 2o. General procedure gave compound 20 as a white solid $(56.2 \mathrm{mg}$, 77\%). m.p. $121-122^{\circ} \mathrm{C}\left[\right.$ lit. $\left.^{42} 123-124^{\circ} \mathrm{C}\right]$. IR (ATR) v 3100-2400 (br), 1530, 1491, 1455, 1427 , 1246, 1075, 999, 884, 734, 694. ${ }^{1} \mathrm{H}$ NMR (400 MHz, DMSO-d6) $\delta$ 7.36-7.24 (m, 5H), 4.28 (s, $2 \mathrm{H}) .{ }^{13} \mathrm{C}$ NMR (100 MHz, DMSO- $\left.d_{6}\right) \delta 155.21,135.89,128.65,128.59,126.94,28.86$. HRMS (ESI) $m / z[\mathrm{M}+\mathrm{H}]^{+}$Calcd for $\mathrm{C}_{8} \mathrm{H}_{9} \mathrm{~N}_{4}$ 161.0827; Found 161.0830.

5-benzhydryl-1H-tetrazole, $2 \mathbf{p}$. General procedure gave compound $\mathbf{2 p}$ as a light brown solid (73 mg, 62\%). m.p. $164{ }^{\circ} \mathrm{C}$ [lit. ${ }^{10} 165-166{ }^{\circ} \mathrm{C}$ ]. IR (ATR) v 3200-2400 (br), 1563, 1524, 1494, 1452, 1243, 1081, 1038, 921, 746, 961. ${ }^{1} \mathrm{H}$ NMR (400 MHz, DMSO- $\left.d 6\right) \delta$ 7.37-7.25 (m, 10H), 5.95 (s, 1H). ${ }^{13} \mathrm{C}$ NMR (100 MHz, DMSO- $\left.d_{6}\right) \delta 158.10,140.04,128.63,128.38,127.13,45.74$. HRMS (ESI) $m / z[\mathrm{M}+\mathrm{H}]^{+}$Calcd for $\mathrm{C}_{14} \mathrm{H}_{13} \mathrm{~N}_{4} 237.1140$; Found: 237.1129.

5-butyl-1H-tetrazole, 2q. General procedure with flow set at $0.04 \mathrm{~mL} / \mathrm{min}$ afforded compound 2q as a beige solid (49 mg, 78\%). m.p. $43{ }^{\circ} \mathrm{C}$ [lit. ${ }^{42} 40-42{ }^{\circ} \mathrm{C}$ ]. IR (ATR) v 3200-2200 (br), $2963,2945,2872,1578,1548,1578,1464,1403,1259,1108,1038,990,930,740 .{ }^{1} \mathrm{H}$ NMR (400 MHz, DMSO-d6) $\delta 2.87$ (t, $J=7.6 \mathrm{~Hz}, 2 \mathrm{H}$ ), 1.67 (quint, $J=7.5 \mathrm{~Hz}, 2 \mathrm{H}$ ), 1.30 (sext, $J=$ $7.5 \mathrm{~Hz}, 2 \mathrm{H}), 0.88$ (t, $J=7.4 \mathrm{~Hz}, 3 \mathrm{H}) .{ }^{13} \mathrm{C}$ NMR (100 MHz, DMSO-d $d_{6} \delta 155.54,29.07,22.33$, 21.49, 13.45. HRMS (ESI) $m / z[\mathrm{M}+\mathrm{H}]^{+}$Caldc for $\mathrm{C}_{5} \mathrm{H}_{11} \mathrm{~N}_{4}$ 127.0978; Found 129.0976. 
5-decyl-1H-tetrazole, 2r. General procedure with flow set at $0.04 \mathrm{~mL} / \mathrm{min}$ afforded compound 2r as a beige solid ( $80 \mathrm{mg}, 76 \%$ ). m.p. $58-59{ }^{\circ} \mathrm{C}$. IR (ATR) $v 3153,3057,2954,2918,2848$, 1566, 1464, 1252, 1093, 1071, 767, 722, 691. ${ }^{1} \mathrm{H}$ NMR (400 MHz, DMSO- $\left.d_{6}\right) \delta 2.85$ (t, $J=7.5$ $\mathrm{Hz}, 3 \mathrm{H}), 1.72-1.64(\mathrm{~m}, 2 \mathrm{H}), 1.27-1.24(\mathrm{~m}, 14 \mathrm{H}), 0.87-0.84(\mathrm{~m}, 3 \mathrm{H}) .{ }^{13} \mathrm{C} \mathrm{NMR}(100 \mathrm{MHz}$, DMSO-d6) $\delta 155.92,31.21,28.85,28.78,28.60,28.45,28.25,26.93,22.61,22.02,13.87$. HRMS (ESI) m/z [M+H] $]^{+}$Calcd for $\mathrm{C}_{11} \mathrm{H}_{23} \mathrm{~N}_{4} 211.1917$; Found 211.1915.

5-(thiophen-2-ylmethyl)-1H-tetrazole, 2s. General procedure with flow set at $0.04 \mathrm{~mL} / \mathrm{min}$ afforded compound $2 \mathrm{~s}$ as a beige solid (77 mg, 93\%). m.p. $224-226{ }^{\circ} \mathrm{C}$ [lit. $\left.{ }^{40} 225-230{ }^{\circ} \mathrm{C}\right]$. IR (ATR) v 3123, 3000-2400 (br), 1557, 1427, 1237, 1038, 924, 700. ' H NMR (400 MHz, DMSOd6) $\delta$ 7.43-7.41 (m, 1H), 7.00-6.97 (m, 2H), $4.52(\mathrm{~s}, 2 \mathrm{H}) .{ }^{13} \mathrm{C}$ NMR (100 MHz, DMSO-d6) $\delta$ 155.03, 137.43, 127.08, 126.62, 125.48, 23.52. HRMS $\left(\mathrm{ASAP}^{+}\right) \mathrm{m} / z[\mathrm{M}+\mathrm{H}]^{+}$Calcd for $\mathrm{C}_{6} \mathrm{H}_{7} \mathrm{~N}_{4} \mathrm{~S}$ 137.0391; Found 167.0390.

Di(1H-tetrazol-5-yl)methane, 2t. Following the general procedure using 4 equiv of $\mathrm{TMSN}_{3}$, a flash chromatography (eluent DCM/MeOH 9:1 + 0.1\% $\left.\mathrm{HCO}_{2} \mathrm{H}\right)$ afforded 2t $(37 \mathrm{mg}, 49 \%)$. m.p. $212{ }^{\circ} \mathrm{C}\left[\right.$ lit. $\left.^{43} 210{ }^{\circ} \mathrm{C}\right]$. IR (ATR) v 3400-2400 (br), 1669, 1554, 1427, 1406, 1367, 1195 , 1141, 1053, 842, 797, 722. ${ }^{1} \mathrm{H}$ NMR (400 MHz, DMSO- $\left.d_{6}\right) \delta 4.73(\mathrm{~s}, 2 \mathrm{H}) .{ }^{13} \mathrm{C} \mathrm{NMR}(100 \mathrm{MHz}$, DMSO- $\left.d_{6}\right) \delta$ 152.44, 18.97. HRMS (ESI) $m / z[\mathrm{M}+\mathrm{H}]^{+}$Calcd for $\mathrm{C}_{3} \mathrm{H}_{5} \mathrm{~N}_{8}$ 153.0632; Found 153.0630 .

4'-methyl-[1,1'-biphenyl]-2-carbonitrile, 5. To a solution of 2-bromobenzonitrile 3 (80 mg, $0.44 \mathrm{mmol}$ ) and poly[4-tolyldibutylstannyl)butyl]styrene (480 $\mathrm{mg}, 0.53 \mathrm{mmol})$ in toluene (5 $\mathrm{mL})$ under argon, was added lithium chloride $(55 \mathrm{mg}, 1.32 \mathrm{mmol})$ and Bis(triphenylphosphine)palladium(II) dichloride (16 $\mathrm{mg}, 0.02 \mathrm{mmol})$. The resulting mixture was left under orbital stirring for 6 hours at $110^{\circ} \mathrm{C}$. The reaction mixture was extracted with diethyl ether and washed with water. The organic layer was separated, washed with water to obtain a crude product. Purification on silica gel (eluent petroleum ether and ethyl acetate, 95:5) afforded 5 (73 $\mathrm{mg}, 86 \%$ ) as a white powder. $\mathrm{mp} 49-50{ }^{\circ} \mathrm{C}\left[\right.$ lit. $\left.^{37,35} 49-51^{\circ} \mathrm{C}\right]$. IR (ATR) $v 3059$, 3022, 2915, 2854, 2225, 1479, 812, $761 \mathrm{~cm}^{-1} .{ }^{1} \mathrm{H}$ NMR (400 MHz, $\left.\mathrm{CDCl}_{3}\right) \delta 7.54(\mathrm{dd}, J=7.7$ $\mathrm{Hz}, J=0.9 \mathrm{~Hz}, 1 \mathrm{H}), 7.62(\mathrm{td}, J=3.8 \mathrm{~Hz}, J=1.2 \mathrm{~Hz}, 1 \mathrm{H}), 7.51(\mathrm{br} \mathrm{d}, J=7.7 \mathrm{~Hz}, 1 \mathrm{H}), 7.48$, $7.31\left(\mathrm{AB}-\right.$ system, $\left.{ }^{2} J_{A B}=8 \mathrm{~Hz}, 2 \mathrm{H}\right), 7.42(\mathrm{td}, J=7.7 \mathrm{~Hz}, J=1.2 \mathrm{~Hz}, 1 \mathrm{H}), 2.43(\mathrm{~s}, 3 \mathrm{H}) .{ }^{13} \mathrm{C} \mathrm{NMR}$ $\left(100 \mathrm{MHz}, \mathrm{CDCl}_{3}\right) \delta 145.7,138.8,135.4,133.8,132.9,130.10,129.6,128.7,127.4,119.0$, 111.3, 21.4; Anal. Calcd for $\mathrm{C}_{14} \mathrm{H}_{11} \mathrm{~N} .0 .05 \mathrm{C}_{4} \mathrm{H}_{8} \mathrm{O}_{2} \mathrm{C} 86.29, \mathrm{H} 5.81, \mathrm{~N} 6.98$; found $\mathrm{C} 86.35, \mathrm{H}$ 5.73, N 6.95. HRMS (ESI) $m / z[\mathrm{M}+\mathrm{Na}]^{+}$Calcd for $\mathrm{C}_{14} \mathrm{H}_{11} \mathrm{NNa} 216.0784$; Found 216.0777. 
4'-(bromomethyl)-[1,1'-biphenyl]-2-carbonitrile, 6. To a solution of sodium bromate (2.71 g, $18 \mathrm{mmol})$ in $\mathrm{H}_{2} \mathrm{O}(9 \mathrm{~mL})$, was added a solution of 4'-methyl-[1,1'-biphenyl]-2-carbonitrile $(1.16 \mathrm{~g}, 6 \mathrm{mmol})$ in ethyl acetate $(6 \mathrm{~mL})$. The mixture was cooled to $0{ }^{\circ} \mathrm{C}$ and a solution of sodium pyrosulfite $(1.82 \mathrm{~g}, 9.6 \mathrm{mmol})$ in $\mathrm{H}_{2} \mathrm{O}(18 \mathrm{~mL})$ was added dropwise. The resulting mixture was stirred at room temperature until the completion of reaction $(\sim 5-6 \mathrm{~h})$. The precipitate was filtered off, washed with cold ethyl acetate, water and isopropanol. The resulting solid was dried under vacuum at $60{ }^{\circ} \mathrm{C}$ to afford $6(1.30 \mathrm{~g}, 80 \%)$ as a white powder. $\mathrm{mp} 125$ $127^{\circ} \mathrm{C}\left[\right.$ lit. $\left.^{44} 126-129^{\circ} \mathrm{C}\right]$. IR (ATR) v 3055, 3030, 2220, $758 \mathrm{~cm}^{-1} .{ }^{1} \mathrm{H}$ NMR $\left(300 \mathrm{MHz}, \mathrm{CDCl}_{3}\right)$ $\delta 7.77$ (br dd, $J=7,7 \mathrm{~Hz}, J=0.9 \mathrm{~Hz}, 1 \mathrm{H}$ ), 7.64 (br td, $J=3.8 \mathrm{~Hz}, J=1.2 \mathrm{~Hz}, 1 \mathrm{H}$ ), 7.58-7.45 $(\mathrm{m}, 5 \mathrm{H}), 7,44$ (br td, $J=3.8 \mathrm{~Hz}, J=1.2 \mathrm{~Hz}, 4.55(\mathrm{~s}, 2 \mathrm{H}) .{ }^{13} \mathrm{C} \mathrm{NMR}\left(75 \mathrm{MHz}, \mathrm{CDCl}_{3}\right) \delta 144.8$, 138.4, 138.3, 133.9, 133.0, 130.1, 129.6, 129.3, 127.9, 118.7, 111.4, 32.9. Anal. Calcd for $\mathrm{C}_{14} \mathrm{H}_{10} \mathrm{BrN}$ C 61.79; H 3.70; $\mathrm{Br} 29.36$; N 5.15; found C 62.09; H 3.47; Br 29.45 N 4.99. HRMS (ESI) $m / z[\mathrm{M}-\mathrm{HCl}+\mathrm{H}]^{+}$Calcd for $\mathrm{C}_{14} \mathrm{H}_{10} \mathrm{NBrNa} 293.9889$; Found 293.9880 .

(S)- $N$-[(2'-cyanobiphenyl-4-yl)methyl]-(L)-valine benzyl ester hydrochloride, 7. To a solution of compound $\mathbf{6}(1.72 \mathrm{~g}, 6.32 \mathrm{mmol})$ and $L$-valine benzyl ester tosylate $(2 \mathrm{~g}, 5.27 \mathrm{mmol})$ in a mixture $1 / 1$ of toluene/ $\mathrm{H}_{2} \mathrm{O}(12 \mathrm{~mL})$, was added $\mathrm{K}_{2} \mathrm{CO}_{3}(1.4 \mathrm{~g}, 13.18 \mathrm{mmol})$, tetrabutyl ammonium bromide $(20 \mathrm{mg}, 0.062 \mathrm{mmol})$ and potassium iodide $(20 \mathrm{mg}, 0.12 \mathrm{mmol})$. The resulting mixture was left under magnetic stirring for 16 hours at $60^{\circ} \mathrm{C}$. After cooling, the two phases separated. The organic layer was washed with water and acidified with hydrochloric acid to $\mathrm{pH}$ 1-2; upon which, the product precipitated which was filtered, washed with toluene and dried to give $7(2.07 \mathrm{~g}, 90 \%)$ as a white powder. $\mathrm{mp} 177^{\circ} \mathrm{C} .[\alpha]^{20} \mathrm{D}=-28.4\left(\mathrm{c}=1, \mathrm{CHCl}_{3}\right)$. IR (ATR) v 2964, 2698, 2563, 2221, 1739, 1550, 1188, 758, $739 \mathrm{~cm}^{-1} .{ }^{1} \mathrm{H}$ NMR (300 MHz, $\left.\mathrm{CDCl}_{3}\right) \delta 7.76(\mathrm{dd}, J=7.7 \mathrm{~Hz}, 1 \mathrm{H}), 7.65-7.58(\mathrm{~m}, 3 \mathrm{H}), 7.53-7.35(\mathrm{~m}, 9 \mathrm{H}), 5.25,5.20$ (ABsystem, $\left.{ }^{2} J_{A B}=11.9 \mathrm{~Hz}, 2 \mathrm{H}\right), 4.38,4.18\left(\mathrm{AB}\right.$-system, $\left.{ }^{2} J_{A B}=13.5 \mathrm{~Hz}, 2 \mathrm{H}\right), 3.47(\mathrm{~d}, J=3.8 \mathrm{~Hz}$, $1 \mathrm{H}), 2.75-2.58(\mathrm{~m}, 1 \mathrm{H}), 1.09(\mathrm{dd}, J=10.9 \mathrm{~Hz}, J=6.9 \mathrm{~Hz}) .{ }^{13} \mathrm{C} \mathrm{NMR}\left(75 \mathrm{MHz}, \mathrm{CDCl}_{3}\right) \delta 166.9$, 144.4, 139.5, 134.7, 134.0, 133.1, 131.6, 130.3, 130.1, 129.6, 129.5, 129.1, 128.8, 128.1, 118.5, 111.3, 68.1, 63.5, 49.8, 29.8, 19.8, 18.0. HRMS (ESI) $m / z[\mathrm{M}-\mathrm{HCl}+\mathrm{H}]^{+}$Calcd for $\mathrm{C}_{26} \mathrm{H}_{27} \mathrm{~N}_{2} \mathrm{O}_{2}$ 399.2063; Found 399.2067.

(S)- $N$-[(2'-cyanobiphenyl-4-yl)methyl]- $N$-valeroyl-(L)-valine benzyl ester, 8: To a solution of compound $7(1 \mathrm{~g}, 2.30 \mathrm{mmol})$ in dichloromethane $(10 \mathrm{~mL})$, was added diisopropylethylamine $(835 \mu \mathrm{L}, 4.79 \mathrm{mmol})$. After cooling at $0{ }^{\circ} \mathrm{C}$, valeroyl chloride $(287 \mu \mathrm{L}, 2.41 \mathrm{mmol})$ was added 
and the mixture was stirred 1 hour between $10-20{ }^{\circ} \mathrm{C}$. Hydrochloric acid $1 \mathrm{~N}$ was poured and the resulting solution was stirred during $15 \mathrm{~min}$. The organic layer was separated, washed with hydrochloric acid $1 \mathrm{~N}$, an aqueous solution of $10 \% \mathrm{NaHCO}_{3}$, brine, dried over anhydrous sodium sulfate, filtered and concentrated to obtain $8(1.06 \mathrm{~g}, 96 \%)$ as an orange oil. $[\alpha]^{20} \mathrm{D}=$ $26.6\left(\mathrm{c}=1, \mathrm{CHCl}_{3}\right)$. IR $(\mathrm{ATR}) v 2964,2698,2563,2221,1739,1550,1188,758,739 \mathrm{~cm}^{-1} .{ }^{1} \mathrm{H}$ NMR (300 MHz, $\left.\mathrm{CDCl}_{3}\right): \delta 7.76(\mathrm{dd}, J=7.7 \mathrm{~Hz}, 1 \mathrm{H}), 7.65-7.58(\mathrm{~m}, 3 \mathrm{H}), 7.53-7.35(\mathrm{~m}, 9 \mathrm{H})$, 5.25, 5.20 (AB-system, $\left.{ }^{2} J_{A B}=11.9 \mathrm{~Hz}, 2 \mathrm{H}\right), 4.38,4.18$ (AB-system, $\left.{ }^{2} J_{A B}=13.5 \mathrm{~Hz}, 2 \mathrm{H}\right), 3.47$ $(\mathrm{d}, J=3.8 \mathrm{~Hz}, 1 \mathrm{H}), 2.75-2.58(\mathrm{~m}, 1 \mathrm{H}), 1.09(\mathrm{dd}, J=10.9 \mathrm{~Hz}, J=6.9 \mathrm{~Hz}) .{ }^{13} \mathrm{C} \mathrm{NMR}(75 \mathrm{MHz}$, $\left.\mathrm{CDCl}_{3}\right) \delta 166.9,144.4,139.5,134.7,134.0,133.1,131.6,130.3,130.1,129.6,129.5,129.1$, 128.8, 128.1, 118.5, 111.3, 68.1, 63.5, 49.8, 29.8, 19.8, 18.0. HRMS (ESI) $m / z[\mathrm{M}+\mathrm{H}]^{+} \mathrm{Calcd}$ for $\mathrm{C}_{31} \mathrm{H}_{35} \mathrm{~N}_{2} \mathrm{O}_{3}$ 483.2643; Found 483.2649.

\section{(S)- $N$-(1-benzyloxycarbonyl-2-methyl-prop-1-yl)- $N$-pentanoyl- $N$-[2'-(1H-tetrazol-5-yl)-}

biphenyl-4-ylmethyl]-amine (Benzyl Valsartan), 9: The general procedure described above was applied to compound 8 (400 $\mathrm{mg}, 0.828 \mathrm{mmol})$ in the presence of azidotrimethylsilane (448 $\mu \mathrm{L}, 3.312 \mathrm{mmol}$ ). The reaction was conducted at $200^{\circ} \mathrm{C}$ with a residence time of $15 \mathrm{~min}$ (flow $=0.04 \mathrm{~mL} / \mathrm{min}$ ). The reaction mixture was collected and concentrated. Ethyl acetate and $\mathrm{NaOH}$ (1M) was added and stirred during $30 \mathrm{~min}$. The aqueous phase was acidified with $\mathrm{HCl}$ until $\mathrm{pH}$ 1-2 and then extracted with ethyl acetate $(200 \mathrm{~mL})$. The organic phase was washed with brine and was dried over magnesium sulfate, filtrated and concentrated under reduced pressure. Purification by chromatography on silica gel (eluent petroleum ether, dichloromethane, methanol (7:2.5:0.5) and 0.1\% formic acid) afforded benzyl valsartan $9(217 \mathrm{mg}, 50 \%)$ as a beige powder. $[\alpha]^{20} \mathrm{D}=-29.8\left(\mathrm{c}=1, \mathrm{CHCl}_{3}\right)$. IR (ATR) $v 2962,2933,2873,1736,1604,1455$, 1410, 1200, 1155, 1106, 997, 848, 755, 738, 726, 697, $599 \mathrm{~cm}^{-1} .{ }^{1} \mathrm{H}$ NMR (300 MHz, $\left.\mathrm{CDCl}_{3}\right)$ : (mixture of rotamers) $\delta 7.8-8.0(\mathrm{~m}, 1 \mathrm{H}), 7.4-7.6(\mathrm{~m}, 2 \mathrm{H}), 7.1-7.4(\mathrm{~m}, 6 \mathrm{H}), 6.8-7.1(4 \mathrm{H}), 4.0-5.0$ $(\mathrm{m}, 5 \mathrm{H}), 2-2.6(\mathrm{~m}, 3 \mathrm{H}), 1.4-1.7(\mathrm{~m}, 2 \mathrm{H}), 1.1-1.4(\mathrm{~m}, 2 \mathrm{H}), 0,7-1(\mathrm{~m}, 9 \mathrm{H}) .{ }^{13} \mathrm{C}$ NMR $(75 \mathrm{MHz}$, $\mathrm{CDCl}_{3}$ ) (mixture of rotamers) $\delta 175.16,175.10,170.51,169.73,155.46,154.86,141.19$, $141.06,138.67,137.99,137.82,136.98,135.38,134.84,131,26,131.20,130.91,130.78$, $129.40,128.98,128.74,128.59,128.41,128.36,128.10,127.77,127.11,126.57,123.07$, $122.77,67.27,66.82,66.43,62.87,49.13,45.90,33.55,33.50,28.16,27.98,27.58,27.39$, $22.47,20.12,19.84,18.95,18.91,13.88$. HRMS (ESI) $m / z[\mathrm{M}+\mathrm{Na}]^{+}$Calcd for $\mathrm{C}_{31} \mathrm{H}_{35} \mathrm{~N}_{5} \mathrm{O}_{3} \mathrm{Na}$ 548.2632; Found 548.2636.

(S)-N-(1-Carboxy-2-methyl-prop-1-yl)- $N$-pentanoyl- $N$-[2'-(1H-tetrazol-5-yl)-biphenyl-4ylmethyl]-amine (Valsartan), 10 : A solution of $200 \mathrm{mg}$ of benzyl valsartan 9 in methanol (5 
$\mathrm{mL}$ ) was hydrogenated at $25^{\circ} \mathrm{C}$ and 5 bar with $\mathrm{Pd}(\mathrm{OAc})_{2}(9 \mathrm{mg}, 0.4 \mathrm{mmol})$ and charcoal (91 $\mathrm{mg}$ ) during $16 \mathrm{~h}$. The solution was placed over a pad of Celite and filtrates were collected. A solution of sodium bicarbonate $(10 \% \mathrm{w} / \mathrm{v})$ was added, the mixture was stirred for 20 minutes and the layers were separated. The aqueous layer was washed with ethyl acetate and the $\mathrm{pH}$ was adjusted to 1-2 with $2 \mathrm{~N}$ hydrochloric acid solution and stirred for 15-30 minutes. The aqueous layer was extracted with ethyl acetate, washed with water and brine. The organic layer was dried over magnesium sulfate and dried under vacuum. Ethyl acetate was added to the residue while hot. Stirred for 5 minutes to obtain a clear solution. The residue was recrystallized with ethyl acetate and cyclohexane. The solid was filtered, washed with a mixture of ethyl acetate/cyclohexane (1:9) and dried to give valsartan (100 mg, 60\%) as a white powder. m.p. $116^{\circ} \mathrm{C}\left[1 \mathrm{it}^{45} 116-117^{\circ} \mathrm{C}\right] .[\alpha]^{25} \mathrm{D}=-65.7\left(\mathrm{c}=1, \mathrm{CHCl}_{3}\right)$. IR (ATR) v 3444, 3057, 2962, 2931, 2877, 2741, 2612, 1732, 1608, 1475, 1410, 1273, 1208, 1167, 1128, 1102, 1051, 999, 939, 899, 852, 824, 777, 762, 685, 677, 628, $560 \mathrm{~cm}^{-1} .{ }^{1} \mathrm{H}$ NMR (300 MHz, DMSO-d6) $\delta 16.25$ (br. s, 1H), 12.63 (br. s, 1H), 7.70-7.52 (m, 4H), 7.21-6.96 (m, 4H), 4.67-4.03 (m, 3H), 2.25-1.99 (m, 2H), 1.59-1.11 (m, 5H), 0.94-0.87 (m, 4H), 0.78-0.69 (m, 5H). ${ }^{13} \mathrm{C}$ NMR (75 MHz, DMSO-d6) $\delta$ 206.36, 173.42, 171.83, 171.57, 141.31, 141.18, 138.19, 137.73, 137.10, 131.00, 130.56, $130.49,128.75,128.24,127.65,127.51,126.90,126.24,65.73,62.93,48.69,45.46,32.42$, 30.62, 27.52, 26.95, 26.76, 21.76, 21.61, 20.09, 19.36, 18.77, 18.46, 13.74, 13.65. HRMS (ESI) $m / z[\mathrm{M}+\mathrm{Na}]^{+}$Calcd for $\mathrm{C}_{24} \mathrm{H}_{29} \mathrm{~N}_{5} \mathrm{O}_{3} \mathrm{Na} 458.2163$; Found 458.2159.

\section{- ASSOCIATED CONTENT}

Supporting Information. This material is available free of charge via the internet at http://pubs.acs.org.

Productivities for compounds 2 , procedure for the preparation of polymer $4,{ }^{1} \mathrm{H}$ NMR and ${ }^{13} \mathrm{C}$ NMR spectra of synthesized products.

\section{- AUTHOR INFORMATION}

\section{Corresponding Author}

*E-mail: erwan.legrognec@univ-nantes.fr

\section{ORCID}

François-Xavier Felpin: 0000-0002-8851-246X

Erwan Le Grognec: 0000-0002-3351-7028

\section{Notes}

The authors declare no competing financial interest. 


\section{- ACKNOWLEDGEMENTS}

We gratefully acknowledge the University of Nantes, the "Centre National de la Recherche Scientifique" (CNRS) and the Société d'Accélération du Transfert de Technologies Ouest Valorisation for financial support. The authors thank I. Louvet and J. Hémez (CEISAM, University of Nantes) for HPLC, GC and HRMS analyses. The authors also thanks M. Paris (IMN, UMR CNRS 6502, University of Nantes) for ${ }^{119}$ Sn MAS NMR experiments.

\section{REFERENCES}

(1) Klapötke, T. M.; Witkowski, T. G. Nitrogen-Rich Energetic 1,2,5-Oxadiazole-Tetrazole Based Energetic Materials. Propellants Explos. Pyrotech. 2015, 40, 366-373.

(2) Popova, E. A.; Trifonov, R. E.; Ostrovskii, V. A. Advances in the synthesis of tetrazoles coordinated to metal ions. Arkivoc 2012, 45-65.

(3) Longbottom, D. A.; Franckevicius, V.; Kumarn, S.; Oelke, A. J.; Wascholowski, V.; Ley, S. V. Practical Organocatalysis with (S)- and (R)-5-Pyrrolidin-2-yl-1H-tetrazoles. Aldrichim. Acta 2008, 41, 3-11.

(4) Ostrovskii, V. A.; Trifonov, R. E.; Popova, E. A. Medicinal chemistry of tetrazoles. Russ. Chem. Rev. 2012, 61, 768-780.

(5) Ostrovskii, V. A.; Popova, E. A.; Trifonov, R. E., Chapter One - Developments in Tetrazole Chemistry (2009-16). In Advances in Heterocyclic Chemistry, Scriven, E. F. V.; Ramsden, C. A., Eds. Academic Press: 2017; Vol. 123, pp 1-62.

(6) Meanwell, N. A. Synopsis of Some Recent Tactical Application of Bioisosteres in Drug Design. J. Med. Chem. 2011, 54, 2529-2591.

(7) Malik, M. A.; Wani, M. Y.; Al-Thabaiti, S. A.; Shiekh, R. A. Tetrazoles as carboxylic acid isosteres: chemistry and biology. J. Incl. Phenom. Macrocycl. Chem. 2014, 78, 15-37.

(8) Roh, J.; Vávrová, K.; Hrabálek, A. Synthesis and Functionalization of 5-Substituted Tetrazoles. Eur. J. Org. Chem. 2012, 6101-6118.

(9) Mittal, R.; Awasthi, S. K. Recent Advances in the Synthesis of 5-Substituted 1H-Tetrazoles: A Complete Survey (2013-2018). Synthesis 2019, 51, 3765-3783.

(10) Gutmann, B.; Roduit, J.-P.; Roberge, D.; Kappe, C. O. Synthesis of 5-Substituted 1H-Tetrazoles from Nitriles and Hydrazoic Acid by Using a Safe and Scalable High-Temperature Microreactor Approach. Angew. Chem. Int. Ed. 2010, 49, 7101-7105.

(11) Gutmann, B.; Obermayer, D.; Roduit, J.-P.; Roberge, D. M.; Kappe, C. O. Safe Generation and Synthetic Utilization of Hydrazoic Acid in a Continuous Flow Reactor. J. Flow Chem. 2012, 2, 8-19.

(12) Palde, P. B.; Jamison, T. F. Safe and Efficient Tetrazole Synthesis in a Continuous-Flow Microreactor. Angew. Chem. Int. Ed. 2011, 50, 1-5.

(13) Chrétien, J.-M.; Kerric, G.; Zammattio, F.; Galland, N.; Paris, M.; Quintard, J.-P.; Le Grognec, E. Tin-Catalyzed Synthesis of 5-Substituted 1H-Tetrazoles from Nitriles: Homogeneous and Heterogeneous Procedures. Adv. Synth. Catal. 2019, 361, 747-757.

(14) Le Grognec, E.; Quintard, J.-P.; Kerric, G.; Chrétien, J.-M.; Zammattio, F. Supported alkoxylated organotin reactant, preparation and use for heterogeneous-phase synthesis of tetrazoles. Patent WO 2013/001235A1, 2013;

(15) Chrétien, J.-M.; Kilburn, J. D.; Zammattio, F.; Le Grognec, E.; Quintard, J.-P., New Trends in the Synthesis of Solid-Supported Organotin Reagents and Interest of their Use in Organic Synthesis in a Concept of Green Chemistry. In Tin Chemistry - Fundamentals, Frontiers and Applications, Davies, A. G.; Gielen, M.; Pannell, K. H.; Tiekink, E. R. T., Eds. John Wiley \& Sons, Ltd: 2008; pp 607-621. (16) Le Grognec, E.; Chrétien, J.-M.; Zammattio, F.; Quintard, J.-P. Methodologies Limiting or Avoiding Contamination by Organotin Residues in Organic Synthesis. Chem. Rev. 2015, 115, 1020710260.

(17) Razzaq, T.; Glasnov, T. N.; Kappe, C. O. Continuous-Flow Microreactor Chemistry under High-Temperature/Pressure Conditions. Eur. J. Org. Chem. 2009, 1321-1325. 
(18) Tsoung, J.; Wang, Y.; Djuric, S. W. Expedient Diels-Alder cycloadditions with orthoquinodimethanes in a high temperature/pressure flow reactor. React. Chem. Eng. 2017, 2, 458-461.

(19) Chen, Y.; Hone, C. A.; Gutmann, B.; Kappe, C. O. Continuous Flow Synthesis of Carbonylated Heterocycles via Pd-Catalyzed Oxidative Carbonylation Using $\mathrm{CO}$ and $\mathrm{O} 2$ at Elevated Temperatures and Pressures. Org. Proc. Res. Dev. 2017, 21, 1080-1087.

(20) Gutmann, B. The Development of High-Temperature/High-Pressure Flow Chemistry - A Tribute to the Pioneering Studies of Jürgen O. Metzger. J. Flow Chem. 2017, 7, 1-3.

(21) Cortés-Borda, D.; Wimmer, E.; Gouilleux, B.; Barré, E.; Oger, N.; Goulamaly, L.; Peault, L.; Charrier, B.; Truchet, C.; Giraudeau, P.; Rodriguez-Zubiri, M.; Le Grognec, E.; Felpin, F.-X. An Autonomous Self-Optimizing Flow Reactor for the Synthesis of Natural Product Carpanone. J. Org. Chem. 2018, 83, 14286-14299.

(22) Rajesh, M.; Jurriaan, H.; Willem, V. Supported Catalysis in Continuous-Flow Microreactors. Adv. Synth. Catal. 2015, 357, 1093-1123.

(23) Denni-Dischert, D.; Derrien, N.; Hirt, H.; Kaufmann, D.; Neville, D.; Schnyder, A.; Sedelmeier, G. Procédé de Fabrication de Valsartan. Patent WO 2004/026847A1, 2004;

(24) Sedelmeier, G.; Rampf, F. A.; Grimler, D. Process for the Manufacture of Organic Compounds. Patent WO 2011/051212A1, 2011;

(25) N, S. K.; Reddy, S. B.; Sinha, B. K.; Mukkanti, K.; Dandala, R. New and Improved Manufacturing Process for Valsartan. Org. Proc. Res. Dev. 2009, 13, 1185-1189.

(26) Bühlmayer, P.; Furet, P.; Criscione, L.; de Gasparo, M.; Whitebread, S.; Schmidlin, T.; Lattmann, R.; Wood, J. Valsartan, a potent, orally active angiotensin II antagonist developed from the structurally new amino acid series. Bioorg. Med. Chem. Lett. 1994, 4, 29-34.

(27) Chrétien, J.-M.; Zammattio, F.; Le Grognec, E.; Paris, M.; Cahingt, B.; Montavon, G.; Quintard, J.-P. Polymer-Supported Organotin Reagents for Regioselective Halogenation of Aromatic Amines. $J$. Org. Chem. 2005, 70, 2870-2873.

(28) Chrétien, J.-M.; Zammattio, F.; Gauthier, D.; Le Grognec, E.; Paris, M.; Quintard, J.-P. Preparation of Allyltin Reagents Grafted on Solid Support: Clean and Easily Recyclable Reagents for Allylation of Aldehydes. Chem. Eur. J. 2006, 12, 6816-6828.

(29) Chrétien, J.-M.; Mallinger, A.; Zammattio, F.; Le Grognec, E.; Paris, M.; Montavon, G.; Quintard, J.-P. Evaluation of Polymer-Supported Vinyltin Reagents in the Stille Cross-Coupling Reaction. Tetrahedron Lett. 2007, 48, 1781-1785.

(30) Kerric, G.; Le Grognec, E.; Zammattio, F.; Paris, M.; Quintard, J.-P. Use of Polymer-Supported Phenyltin for the Creation of Aryl-Aryl or Aryl-Heteroaryl Bonds via Stille Cross-Coupling Reactions. J. Organomet. Chem. 2010, 695, 103-110.

(31) Kerric, G.; Le Grognec, E.; Fargeas, V.; Zammattio, F.; Quintard, J.-P.; Biesemans, M.; Willem, R. Synthesis, Characterization and Primary Evaluation of the Synthetic Efficiency of Supported Vinyltins and Allyltins. J. Organomet. Chem. 2010, 695, 1414-1424.

(32) Beutler, U.; Boehm, M.; Fuenfschilling, P. C.; Heinz, T.; Mutz, J.-P.; Onken, U.; Mueller, M.; Zaugg, W. A High-Throughput Process for Valsartan. Org. Proc. Res. Dev. 2007, 11, 892-898.

(33) Reddy, M. M.; Reddy, K. H.; Reddy, M. U. Harmonized Guideline on Limit and Testing of Elemental Impurities in Pharmaceutical Substances: A Review. Pharmaceut. Reg. Affairs 2016, 5, 168175.

(34) Shen, H. C., Selected Applications of Transition Metal-Catalyzed Carbon-Carbon CrossCoupling Reactions in the Pharmaceutical Industry. In Applications of Transition Metal Catalysis in Drug Discovery and Development - an Industrial Perspective, Wiley: Hoboken, NJ, 2012; pp 25-95.

(35) Information on nitrosamines for marketing authorisation holders. European Medicines Agency 2019, EMA/189634/2019.

(36) Demko, Z. P.; Sharpless, K. B. Preparation of 5-Substituted 1H-Tetrazoles from Nitriles in Water. J. Org. Chem. 2001, 66, 7945-7950.

(37) Bonnamour, J.; Bolm, C. Iron Salts in the Catalyzed Synthesis of 5-Substituted 1H-Tetrazoles. Chem. Eur. J. 2009, 15, 4543-4545.

(38) Cousaert, N.; Willand, N.; Gesquiere, J.-C.; Tartar, A.; Deprez, B.; Deprez-Poulain, R. Original loading and Suzuki conditions for the solid-phase synthesis of biphenyltetrazoles. Application to the first solid-phase synthesis of irbesartan. Tetrahedron Lett. 2008, 49, 2743-2747.

(39) Aureggi, V.; Sedelmeier, G. 1,3-Dipolar Cycloaddition: Click Chemistry for the Synthesis of 5Substituted Tetrazoles from Organoaluminum Azides and Nitriles. Angew. Chem. Int. Ed. 2007, 46, 8440-8444. 
(40) Lenda, F.; Guenoun, F.; Tazi, B.; Iarbi, N. B.; Allouchi, H.; Martinez, J.; Lamaty, F. Synthesis of new tetrazole-substituted pyroaminoadipic and pipecolic acid derivatives. Eur. J. Org. Chem. 2005, 326-333.

(41) Joo, Y.-H.; Shreeve, J. n. M. Functionalized Tetrazoles from Cyanogen Azide with Secondary Amines. Eur. J. Org. Chem. 2009, 3573-3578.

(42) Jin, T.; Kitahara, F.; Kamijo, S.; Yamamoto, Y. Synthesis of 5-Substituted 1H-Tetrazoles by the Copper-Catalyzed [3+2] Cycloaddition of Nitriles and Trimethylsilyl Azide. Chem. Asian J. 2008, 3, $1575-1580$.

(43) Zubarev, V. Y.; Trifonov, R. E.; Poborchii, V. V.; Ostrovskii, V. A. Polynuclear Branched Tetrazole Systems. Acidity of alpha,omega-Ditetrazol-5-ylalkanes. Chem. Hetereocycl. Compd. 2006, 42, 469-474.

(44) Kumar, M. R.; Park, K.; Lee, S. Synthesis of Amido-N-imidazolium Salts and their Applications as Ligands in Suzuki-Miyaura Reactions: Coupling of Hetero- aromatic Halides and the Synthesis of Milrinone and Irbesartan. Adv. Synth. Catal. 2010, 352, 3255-3266.

(45) Zhang, C. X.; Zheng, G. J.; Bi, F. Q.; Li, Y. L. A Simple and Efficient Synthesis of the Valsartan. Chin. Chem. Lett. 2008, 19, 759-761. 